\title{
Principal Leadership Contribution to Development Characteristics of Competence Professional Teacher
}

\author{
Siraj \\ Study Program of Educational Management \\ Postgraduate Program University of Medan \\ Medan, North Sumatera, Indonesia \\ raj.fisumuslim@gmail.com
}

\author{
Sri Milfayetty \\ Postgraduate Program University of Medan \\ University of Medan \\ Medan, North Sumatera, Indonesia \\ milfayetty@yahoo.com
}

\begin{abstract}
This study aimed to contribute to the empowerment of the leadership of the principal characteristics of the professional competence of teachers, as well as obstacles in the empowerment of the characteristics of the professional competence of teachers Junior High School (SMP) in Gandapura. The research method used is descriptive method with qualitative approach. The research instruments are interview, observation and documentation. Research subjects are principals, vice principals and teachers. The results showed that the principal contribution to the empowerment of the characteristics of the professional competence of teachers is teachers have a good implementation of learning management supported by the existence of infrastructure sufficient learning, increased teacher professionalism through teacher commitment to the quality of learning, teaching, learning and teacher performance. Obstacles are found in the teachers performance management and learning management still lack the use of technology in learning.
\end{abstract}

Keywords-Principal, characteristics, teacher professional

\section{INTRODUCTION}

Principal leadership is one of the dominant factors in improving the quality of education in schools. The principal task of the principal is to manage and organize educational services for all learners in schools to achieve quality education. In order to achieve quality education, schools must have professional teachers. Welker (1992) argues that professionalism of teachers can be achieved if the expert teachers (expert) in carrying out the task, and always develop themselves. This is because teachers play an important and strategic role in a learning process. The learning process as an activity to improve knowledge, skills and attitudes is directly related to teacher activity. As an activity system, the learning process involves teachers starting from the selection and sorting of learning materials, the application and use of learning methods, the delivery of learning materials, the guidance of learning, to the evaluation of learning outcomes.

Boyd (1989) argues that teacher performance evaluation is designed to serve two purposes: 1) to measure teacher competence and 2) support professional development. Professional competence is one of the elements that must be owned by the teacher is by mastering the learning materials widely and deeply. According to Suprihatiningrum (2013) professional competence is a capability related to the mastery of learning materials in the field of study broadly and deeply covering the mastery of scientific substance that overshadows the curriculum material, as well as increasing the knowledge of science as a teacher.
The result of observation at Junior High School (SMP) of Gandapura found that the establishment of professional ability and attitude of teacher is not easy, not necessarily the professional ability of teachers will also formed also professional attitude, because many factors determine it. Although teachers have been educated in the field of education, not necessarily automatically also form these professional skills and attitudes. Because the educational program being studied may or may not emphasize this professional capacity building and attitude program. Increased professionalism of teachers is naturally done, not only by the government but from themselves the teacher must also have the willingness to be more professional so that the goal of national education is achieved.

The low teacher professionalism is due to the absence of changes in teaching patterns and conventional systems to competence systems, high teacher workload, and many teachers who have not done classroom action research. On that basis the standard of competence is formed in order to really form a professional teacher and have the appropriate competence in teaching. Campbell et. al (2016) argues that teacher performance assessments are conducted to identify effective teachers in the form of teacher knowledge, skills and competence.

In accordance with the research problem, the purpose of the research is to know the contribute to the empowerment of the leadership of the principal characteristics of the professional competence of teachers, as well as obstacles in the empowerment of the characteristics of the professional competence of teachers Junior High School (SMP) in Gandapura.

\section{METHOD}

The research method used is descriptive method with qualitative approach. Sources of data in the study are principals, vice principals and teachers at Junior High School (SMP) Gandapura Bireuen District. Data collection techniques in this study is through interviews, observation and documentation. Data analysis technique used is descriptive technique by taking three steps that happened simultaneously according to Miles and Huberman (1992) that is: (1) data reduction, (2) data displays, (3) verification. 


\section{FINDING AND DISCUSSION}

The ability of teachers in mastering teaching materials is a basic competency that requires professional competence of teachers. Based on data revealed from the field, shows that the ability of teachers in terms of mastery of learning materials varied considerably. The results of interviews with teachers to find some efforts made by teachers in preparing the mastery of teaching materials. First, study the scope of the teaching program in each subject or in each meeting. Recognized by the teachers, the existence of routine activities in terms of subjects he held, causing the preparation of mastery of teaching materials is not a serious problem. Second, create or formulate the teaching material delivery steps into the learning implementation plan format (RPP). According to the teachers, that the format of learning implementation plan used by teachers Junior High School (SMP) of Gandapura use the following format: (a) identity; (b) basic competence and competency standards; (c) indictors and learning objectives, (d) subject matter, (e) teaching and learning activities (f) evaluation, and $(\mathrm{g})$ learning resources.

The management of teaching and learning program is the implementation of the learning program formulated in the learning implementation plan. From the results of interviews with teachers, found that efforts made to improve mastery of the management of teaching and learning programs is first by doing an understanding and deepening of the implementation plan of learning to be delivered. There are even some teachers, who specially allocate time to do the understanding and deepening of each unit of learning a day before the learning process. Through these efforts, mastery in the management of teaching and learning programs can be implemented in accordance with the target or at least close to the planned targets. In entering the implementation of the teaching and learning program, some teachers do pre-test as a way to measure the basic skills of the students so that it is expected that the teaching and learning programs are conducted in accordance with the basic skills of students.

The use of media or learning resources is another supporting component that can encourage the realization of an effective teaching and learning process and conducive classroom management. The ability of teachers in using media or learning resources has not been entirely based on the analysis of the effectiveness of learning, but tends to be based on consideration of the utilization of existing facilities in schools. This was revealed by interviews with some teachers that the motivation in using props was based on the consideration of the utilization of existing facilities in schools, so that their use was carried out inconsistently and not touching with the principles of relevance and validity with the subject matter presented.

Mastering the educational foundations, some of the knowledge that the teacher understands about the educational base in relation to the teaching and learning process, is the understanding of students, the ethics of the teaching profession, the principles of motivating student learning, school relations with the community, and other aspects related to main tasks and functions as educators.
Teacher profession ethics is an educational foundation that teachers need to understand in raising awareness, willingness, and ability to serve their duties as educators. The results of interviews with teachers, generally teachers have a clear understanding of what it is profession, professionalism, and professionalism

The interaction of teachers with students in teaching and learning process is the core of the overall task and function of teachers as educators. Based on the results of classroom observations, indicating that the interaction of teachers with students in the learning process is a form of application or action of teachers on the formulation of the planned implementation of learning that has been formulated. The ability of teachers in managing the interaction of teaching and learning process is seen in the case of: (1) systematically delivering the lesson material; (2) regulates communication traffic between teachers and students and between students and students; (3) and direct the discussion or discussion in the classroom that is appropriate for the specific learning objectives.

Teaching evaluation is another important skill the teacher must possess. The results of interviews with teachers, and classroom observations, indicate that the evaluation of teaching conducted by teachers, grouped in daily tests, midterm replay and semester final repetition for first and second grade, while for third grade in addition to daily repeat, semester there is also Final School Exam (UAS), evaluation at each end of the subject, mid semester evaluation, and evaluation at the end of evaluation.

Implementation of guidance and counseling in schools is an important part of the overall learning process at school. Guidance and counseling, an educational service that requires specialized personnel, and even if the implementation is not handled by the counselor profession, then it is carried out by senior teachers.

Carry out school administration in addition to his duties as an educator, teachers are also faced with school administration tasks. Some of the school administration teachers do, among other lesson units, semester programs of student attendance lists, grid questions, evaluation books, student score lists, and student personal notes.

Understanding the principles of classroom research, from the results of interviews with teachers and documenting study, generally teachers of SMP Negeri Gandapura not fully understand the function of the teaching profession in terms of classroom research. Teachers see that classroom research is the activity of a series of teacher professions. The demands of the teaching profession, in its perceptions tend to be limited in the implementation of teaching and learning process, from planning, implementation, evaluation, and follow-up. Even if there are teachers who conduct research, it is more based on credit interests in proposing promotion, so the intensity is still rarely implemented by teachers.

Based on field data obtained that the strength that affects the professional competence of teachers Gandapura Affairs is the internal coaching and formulation of vision, mission, achievement strategy that can be used as a reference for teacher 
performance. Internal guidance by principals plays an important role in improving the professionalism of teachers. While the vision and mission is the basic framework and operational base that can be used as a guide for teachers in carrying out professional duties. Concerning external factors, SMP Negeri Gandapura teachers are faced with global conditions characterized by public awareness (parents and community) in highlighting educational outcomes and orientation of educational development that lead to quality improvement.

In an effort to improve the professional competence of teachers, the role of the principal as a supervisor becomes something that should be applied to every school organization. The principal has the task of developing the performance of personnel, especially improving the professional competence of teachers. The role of the principal as a supervisor can generally be done through assistance to teachers especially in the learning process, encouraging teachers in the work, and engaging teachers in activities that support the improvement of professional competence. The low role of the principal as a supervisor in the development of professional competence of teachers to be questionable, this is because the many tasks and responsibilities of the principal to be one reason for the lack of supervision in the school. In fact, it is not uncommon for principals to emphasize only on the administrative responsibilities of teachers without paying attention to the coaching of their more important professional competencies. Implementation of supervision by the principal should be done continuously given the increase in professional competence of teachers cannot be done instantly. As a supervisor, the principal must be able to understand the characteristics and conditions of each teacher so that what is the essence or purpose of supervision can be achieved. In addition, the principal must also be able to plan, implement, and make follow-up of the results of supervision.

Based on the results of interviews with the principal suggests the principal obstacles in improving teacher competence are: (1) lack of teachers' intention to become professional teachers; (2) the lack of time to exchange experiences with other teachers is certainly about good teaching-learning experiences; (3) lack of interest of teachers to innovate; and (4) modern facilities that support the teaching and learning process. Like computers, LCDs, and other media. The results of Buto (2016) showed that the development of teacher professionalism competence has not fully developed. Constraints to the development of teacher professional competence include teacher training in place, lack of fund allocation for teacher professionalism, decreased motivation to develop teacher professional competence, and lack of teacher ability in technology and information mastering. Further research results Wiyono, Kusmintardjo, and Supriyanto (2014) also found that based on the results of correlation analysis between coaching factors implemented, both in terms of technical frequency, guiding principles, coaching approach, and place of guidance, the outline of teacher training implemented has not yet had a significant impact on teacher performance.

Based on the obstacles faced in order to increase the professionalism of teachers, has been pursued a solution through the development of knowledge and technical skills through the empowerment of teacher competence, listening to input or direction about the importance of a discipline in carrying out the learning process on a regular basis, so that teachers can comply with school rules and rules binding personnel, so that all elements of education in the school can adhere to the mechanisms and procedures of applying the discipline applied and with various administrative demands of learning, the school has set up computer devices such as laptops with various formats of instructional administration to each teacher, especially in learning activities, so allowing the work to be done does not feel heavy, and runs optimally.

\section{CONCLUSIONS AND SUGGESTIONS}

The results showed that the principal contribution to the empowerment of the characteristics of the professional competence of profesional teachers have a good implementation of learning management supported by the existence of infrastructure sufficient learning, increased teacher professionalism through teacher commitment to the quality of learning, teaching, learning and teacher performance. Obstacles are found in the teachers performance management and learning management still lack the use of technology in learning.

To the stakeholders, to pay attention to the obstacles and difficulties of teachers in the field, so the need for better coaching through upgrading, training, seminars, workshop, etc. in order to improve teacher performance and professionalism.

\section{ACKNOWLEDGMENT}

Acknowledgments are submitted to the Director of Graduate Programs State University of Medan. The Committee of AISTEEL-2017. Finally, thank you to the principals and teachers at Junior High School of Gandapura Bireuen District.

\section{REFERENCES}

[1] B. Budi Wiyono, Kusmintardjo, and A. Supriyanto, "Grand Design Model Pembinaan Profesional Guru Berbasis Determinan Kinerja Guru," Jurnal Ilmu Pendidikan, Jil. 20, No. 2, 2014, pp. 165-175.

[2] C. Campbell. C. Cuauhtémoc Ayala, G. Railsback, F. W. Freking, C. McKenna, and D. Lausch, "Beginning teachers' perceptions of the California Teaching Performance Assessment (TPA)," Teacher Education Quarterly, Vol. 43, No. 2, 2016, pp. 51-71.

[3] E. Mulyasa, Uji Kompetensi dan Penilaian Kinerja Guru. Bandung: Remaja Rosdakarya, 2013.

[4] J.H. Stronge, Evaluating Teaching A Guide to Current Thinking and Best Practice ( $2^{\text {nd }}$ eds). California: Corwin Press, 2006

[5] J. Suprihatingrum, Guru Profesional. Yogjakarta: Ar-Ruzz Media, 2013.

[6] M. B. Miles and A. Michael Huberman, Qualitative Data Analysis: An Expanded Sourcebook. California: Sage Publications, 1992.

[7] R.T. C Boyd, "Improving Teacher Evaluations; Practical Assessment, Research \& Evaluation," Apeer-reviewed Electronic Journal, Vol. 1, No. 7, 1989, pp. 1-3.

[8] R.W. Rebore, Personel Administration in Education. Prentice-Hall, 1987.

[9] R. Welker, The Teacher as Expert: A Theoretical and Historical Examination. Albany: State University of New York Press, 1992

[10] Z. Ali Buto, "Pengembangan Kompetensi Profesionalisme Guru PAI di Aceh," Miqot, Vol. 9 No. 2, 2016, pp. 370-389. 